\author{
L.K. Patrylak, O.P. Pertko, V.A. Povazshnyi, O.V. Melnychuk
}

\title{
INFLUENCE OF MODIFICATION BY Zr AND La ON THE POROUS CHARACTERISTICS AND CATALYTIC ACTIVITY OF IN SITU SYNTHESIZED MICROSPHERICAL CRACKING CATALYSTS
}

\author{
V.P. Kukhar Institute of Bioorganic Chemistry and Petrochemistry of the National Academy of Sciences \\ of Ukraine, Kyiv, Ukraine
}

\begin{abstract}
Up-to-date fluid catalytic cracking catalysts for large-tonnage refining processes work under extremely hard conditions and need to have a high stability to the thermal and steam treatment. Therefore, the purpose of this work was to compare the effect of lanthanum and zirconium additives on the porous characteristics and catalytic activity of the microspherical cracking catalysts in fresh and steamed form that were synthesized based on the Ukrainian kaolin. The synthesized initial sample contained 30\% Y zeolite that was transferred to the $\mathrm{H}$-form before the modification by lanthanum and zirconium. The modification led to some decrease in BET surface and samples microporosity, which was substantially intensified after steaming. In the case of zirconium, such a decrease was less than for lanthanum. The effect of the catalysts modification on the vibrations of the structural components of the zeolite lattice was investigated by FTIR spectroscopy. The observed shifts of absorbance frequencies of the bond at $1070 \mathrm{~cm}^{-1}$, which correspond to the asymmetric vibrations of tetrahedra after corresponding modifications, indicated the isomorphic substitution of the aluminum atoms by zirconium ones. The steamed samples with the zirconium content of $6.5 \%$ demonstrated the highest conversion of cumene cracking (an increase by $20-30 \%$ as compared with the unmodified sample). Therefore, the modification of fluid catalytic cracking catalysts by zirconium affects both on the adsorption and on the catalytic properties of the steamed samples.
\end{abstract}

Keywords: fluid catalytic cracking catalyst, zirconium, lanthanum, porous characteristics, catalytic activity.

DOI: $10.32434 / 0321-4095-2019-127-6-157-163$

\section{Introduction}

Catalytic cracking is a well-known and important refining process that aims to increase the yield of gasoline products [1-4]. Zeolite catalysts, especially their acidic forms that display carboniogenic activity, belong to the most important groups of modern catalysts for petroleum processing and petrochemistry. Zeolite $\mathrm{Y}$ or ZSM-5 is traditionally used as an active phase of the fluid catalytic cracking (FCC) catalysts. However, the extremely hard conditions of catalyst life cycle in reactor $\left(450^{\circ} \mathrm{C}, 1-3 \mathrm{~s}\right)$ and regenerator $\left(750^{\circ} \mathrm{C}, 20-\right.$ $30 \mathrm{~min}$ ) significantly decrease its activity and stability. Matrix phase in a certain way reduces this negative impact [5]. The effect of the matrix is particularly substantial in the case of in situ synthesis of zeolite on the basis of natural kaolin [6,7]. It is known that the presence of lanthanum in the zeolite structure improves Lewis acidity and thermostability of zeolites [5,8-10]. Therefore, the search for new stabilizers of the zeolite phase is an urgent task.

The purpose of this work was to compare the effect of lanthanum and zirconium additives on the porous characteristics and catalytic activity of the FCC catalysts in fresh and steamed form that were synthesized based on the Ukrainian kaolin.

\section{Experimental}

Catalyst synthesis

Y zeolite-containing microspheres (ZCM) were synthesized in situ by a method similar to that described elsewhere [6-8,11] on the basis of the Ukrainian kaolin (Prosyana, Dnipropetrovs'k region). Kaolin microspheres $(40-100 \mu \mathrm{m})$ were fabricated by spray drying of the kaolin-water slurry. The last 
were divided into two parts, each being calcined at 700 and $950-980^{\circ} \mathrm{C}$ for $2 \mathrm{~h}$ to convert the parent kaolin into metakaolin and a mixture of reactive silica with an aluminium silicate spinel. Both parts were used for zeolite synthesis in aqueous solution of $\mathrm{NaOH}$. As a result, zeolite phase was synthesized only on the surface of microspheres. The main part of them consists of unconverted metakaolin and alumosilicate spinel.

The hydrogen form (H-FCC) was prepared by four-fold ion exchange of native sodium cations for ammonium ones using ammonium nitrate solution $\left(3 \mathrm{~mol} \mathrm{dm}^{-3}\right)$ with intermediate calcinations at $550^{\circ} \mathrm{C}$ for 2 hours. Lanthanum and zirconium were introduced by ion exchange using aqueous solution of $1 \mathrm{~mol} \mathrm{dm}^{-3}$ lanthanum nitrate (HLa-FCC) and 0.04 (H4Zr-FCC) or 0.06 (H6Zr-FCC) $\mathrm{mol} \mathrm{dm}^{-3}$ zirconil oxynitrate, respectively.

\section{Catalyst characterization}

Porous characteristics of the synthesized samples were investigated via low-temperature $\left(-196^{\circ} \mathrm{C}\right)$ nitrogen adsorption/desorption isotherms measured using Nova 1200e (Quantochrome) porometer. The specific surface areas $\left(\mathrm{S}_{\mathrm{BET}}\right)$ were calculated according to the BET method utilizing the nitrogen adsorption data at $\mathrm{P} / \mathrm{P}_{0}$ values of 0.06 to 0.2 . The micropores volumes $\left(\mathrm{V}_{\text {micro }}{ }\right)$ and micropores surface areas $\left(\mathrm{S}_{\text {micro }}^{\mathrm{t}}\right)$ were estimated using the de Boer t-plot method.

$\mathrm{X}$-ray diffraction study was performed by using a DRON-4-07 diffractometer with the Ni filtered $\mathrm{CuK}_{\alpha}$ radiation in a reflected beam at the BraggBrentano focus geometry in the range $2 \theta=5-35^{\circ}$ with an exposure step of 0.05 or $1 \mathrm{~s}$.

$\mathrm{X}$-ray fluorescence analysis was used in investigation of chemical compositions of the samples.

Modeling of the sample stabilization process in the FCC reactor-regenerator system was carried out by catalyst treating in pure water vapor at a high temperature. Steaming was performed in a set-up [11], in which the catalyst steamer was capable of providing a temperature as high as $1000^{\circ} \mathrm{C}$ in a pure steam flow at a pressure of $0.1 \mathrm{MPa}$. The catalyst steamer was supplied with two control thermocouples. A flash water boiler also formed a part of the set-up, being interlocked with the steamer by a steam conduit and supplied with its own electrical heater to achieve the temperature of $200^{\circ} \mathrm{C}$. The superheated steam passed into the steamer with the catalyst bed from a bottom and then removed from the open top part of the cylinder. The samples after steaming at $800^{\circ} \mathrm{C}$ during 2 hours are designated as TWT.

\section{Catalytic tests}

Catalytic properties of FCC catalysts were studied in cumene cracking utilizing micro pulse setup based on gas chromatograph which was equipped with a flame ionization detector [7,11]. Catalyst sample $(0.1 \mathrm{~g})$ was dehydrated firstly in a in a helium flow $\left(0.5 \mathrm{~L} \mathrm{~h}^{-1}\right)$ with increasing $\left(20^{\circ} \mathrm{C} \mathrm{min}^{-1}\right)$ reactor temperature up to $500^{\circ} \mathrm{C}$, followed by exposure of the sample to this temperature for $1 \mathrm{~h}$. The temperature was then decreased to its operational value. The reaction was studied at $320^{\circ} \mathrm{C}$ for fresh samples and at $400^{\circ} \mathrm{C}$ for steamed samples. High purity helium was used as a carrier gas $\left(10 \mathrm{~mL} \mathrm{~min}{ }^{-1}\right)$. Cumene was injected by pulses of $1 \mu \mathrm{L}$ using micro syringe in the helium stream. The products were collected and cooled by liquid nitrogen trap $\left(-196^{\circ} \mathrm{C}\right)$ and further analyzed online using flame ionization detector after vaporizing by thermal impulse of $200^{\circ} \mathrm{C}$. Packing column with an internal diameter of $3 \mathrm{~mm}$ and a length of $2 \mathrm{~m}$ was used with a stationary phase «Inerton AW-10-dimethylchlorosilane» (fraction of $0.2-0.25 \mathrm{~mm}$ ) impregnated by $5 \mathrm{wt} . \%$ of an active phase XE-60.

Propane and benzene were the main cracking products, admixtures of toluene, ethylbenzene and unconverted cumene were also detected. The number of pulses used for testing of each sample was 8 .

\section{Results and discussion}

According to the XRD data, the crystalline zeolite phase of samples is $\mathrm{Y}$ zeolite. Fourteen characteristics peaks for faujsite zeolite $\mathrm{Y}$ were identified $(2 \theta=10.1,11.8,15.6,18.6,20.3,22.7,23.6$, $25.7,26.9,29.5,30.6,31.3,32.4$, and $\left.33.9^{\circ}\right)$. XRD results revealed the zeolite phase content in the fresh H-FCC sample of about $30 \%$ (Fig. 1). After steaming, the H-FCC-TWT sample contains $10 \%$ of zeolite, whereas HLa-FCC-TWT and zirconium-containing samples contain $12 \%$ and $15 \%$, respectively.

XRF analysis of the H-FCC sample showed $73 \% \mathrm{SiO}_{2}$ and $27 \% \mathrm{Al}_{2} \mathrm{O}_{3}$. Lanthanum content in the sample HLa-FCC was $4 \%$, while zirconiumcontaining samples revealed slightly more lanthanum: $5.5 \%$ and $6.5 \%$ in $\mathrm{H} 4 \mathrm{Zr}-\mathrm{FCC}$ and $\mathrm{H} 6 \mathrm{Zr}-\mathrm{FCC}$ samples, respectively.

Figure 2 shows the data on the low temperature nitrogen adsorption/desorption isotherms of fresh and steamed zeolite-containing samples. The isotherms for FCC catalysts demonstrate the existence of equilibrium Langmuir branches at low $\mathrm{P} / \mathrm{P}_{\mathrm{o}}$ values and hysteresis loops over higher values, i.e. in the mesopore range. Such isotherms are typical of zeolite particles embedded in a matrix phase [7]. The isotherms belong to IVa type with $\mathrm{H} 4$ hysteresis loop 


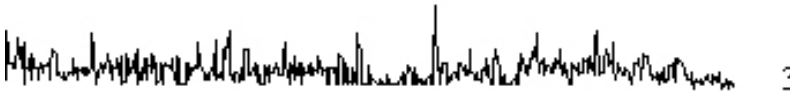

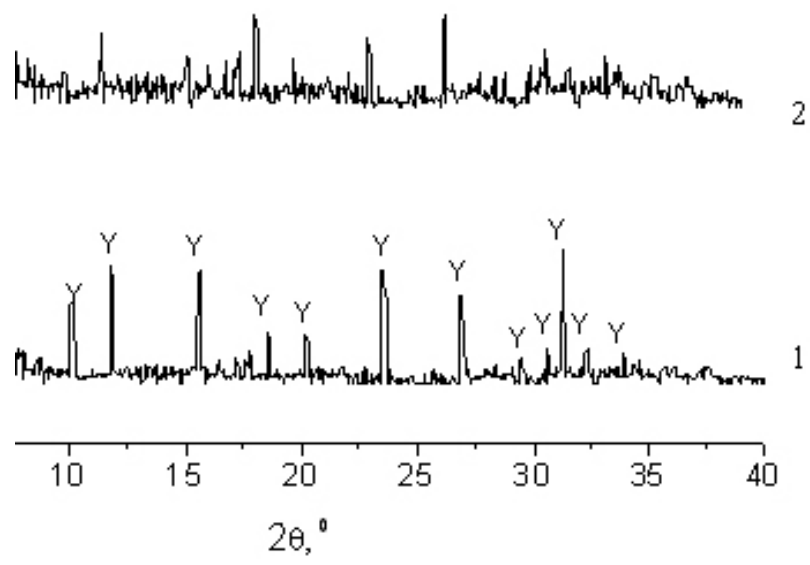

Fig. 1. XRD patterns of catalyst samples:

1 - H-FCC, 2 - steamed zirconium-containing samples, and $3-\mathrm{H}-\mathrm{FCC}-\mathrm{TWT}$

according to the IUPAC classification [12]. The presence of the hysteresis loops demonstrates the implementation of capillary condensation in the pores.

Porous characteristics are summarized in Table. A decrease in the BET surface for fresh samples after modification is not critical and amounts to 13$37 \mathrm{~m}^{2} \mathrm{~g}^{-1}$. Then after water vapor treatment, one can see an essential decrease in the BET surface and micropores surface of the catalyst samples. Moreover, the addition of zirconium significantly affects the adsorption characteristics, whereas the modification by lanthanum has only a little effect on these parameters.

The modification by zirconium contributes to the preservation of a larger fraction of the BET surface after TWT (157 and $134 \mathrm{~m}^{2} \mathrm{~g}^{-1}$ versus $121 \mathrm{~m}^{2} \mathrm{~g}^{-1}$ ), while the modification by lanthanum, on the contrary, causes a decrease in the surface to $106 \mathrm{~m}^{2} \mathrm{~g}^{-1}$ with the same micropore content as in the H-FCC-TWT sample. After modifying the fresh samples, the average pore radius decreases slightly. Apparently, this is due to the introduction of cations larger than the proton size. As a result, both modifiers contribute to a smaller expansion of the medium pore radius after steaming than for an unmodified hydrogenform sample. Moreover, this size is a bit smaller for zirconium than for lanthanum.

Therefore, in addition to XRD results, nitrogen adsorption data confirmed a smaller destruction of zeolite phase during TWT treatment for the Zr-containing samples.

Porous characteristics of the fresh and steamed FCC catalysts

\begin{tabular}{l|c|c|c|c|c}
\hline \multicolumn{1}{c|}{ Sample } & $\begin{array}{c}\mathrm{S}_{\mathrm{BET}}, \\
\mathrm{m}^{2} \mathrm{~g}^{-1}\end{array}$ & $\begin{array}{l}\mathrm{S}_{\text {micro, }}^{\mathrm{t}} \\
\mathrm{m}^{2} \mathrm{~g}^{-1}\end{array}$ & $\begin{array}{c}\mathrm{V}_{\text {total, }} \\
\mathrm{cm}^{3} \mathrm{~g}^{-1}\end{array}$ & $\begin{array}{c}\mathrm{V}_{\text {micro, }}^{\mathrm{t}} \\
\mathrm{cm}^{3} \mathrm{~g}^{-1}\end{array}$ & $\begin{array}{c}\mathrm{R}, \\
\mathrm{nm}\end{array}$ \\
\hline H-FCC & 275 & 135 & 0.41 & 0.059 & 2.95 \\
\hline H-FCC-TWT & 121 & 29.3 & 0.30 & 0.012 & 4.99 \\
\hline HLa-FCC & 238 & 125 & 0.34 & 0.054 & 2.82 \\
\hline HLa-FCC-TWT & 106 & 28.0 & 0.24 & 0.012 & 4.54 \\
\hline H4Zr-FCC & 266 & 130 & 0.37 & 0.054 & 2.82 \\
\hline H4Zr-FCC-TWT & 157 & 31.4 & 0.30 & 0.013 & 4.48 \\
\hline H6Zr-FCC & 262 & 128 & 0.36 & 0.055 & 2.70 \\
\hline H6Zr-FCC-TWT & 134 & 33.3 & 0.35 & 0.014 & 4.46 \\
\hline
\end{tabular}

The IR spectra of the synthesized catalysts are shown in Fig. 3. Vibrations of the frameworks of zeolites give rise to typical bands [10]. Sample $\mathrm{H}-\mathrm{FCC}$ demonstrate an intensive band at $1070 \mathrm{~cm}^{-1}$ both in fresh and in TWT form, which corresponds to the internal asymmetric vibrations of $\mathrm{TO}_{4}$ tetrahedra, where $\mathrm{T}$ is aluminium or silicon [13]. Modification by La or $\mathrm{Zr}$ leads to the shift of this band to the lower frequency region $\left(1030-1060 \mathrm{~cm}^{-1}\right)$, which indicates the formation of $\mathrm{La}-\mathrm{O}-\mathrm{Si}(\mathrm{Al})$ or $\mathrm{Zr}-\mathrm{O}-\mathrm{Si}(\mathrm{Al})$ bonds. The presence of the latter is also confirmed by the shoulder at $1200-1150 \mathrm{~cm}^{-1}$ in the zeolite spectra as the result of asymmetric stretching vibrations of the external linkages of the primary zeolite structural units. In the case of lanthanum, the shift of $1070 \mathrm{~cm}^{-1}$ bond is significantly more sensitive $\left(40 \mathrm{~cm}^{-1}\right)$, whereas for zirconium it is 10 and $20 \mathrm{~cm}^{-1}$ only (greater displacement in the case of higher zirconium content).

After the TWT treatment, the lanthanumcontaining sample is only partially turning towards the high-frequency region showing a band at $1040 \mathrm{~cm}^{-1}$, whereas almost complete return to the frequency at $1070 \mathrm{~cm}^{-1}$ takes place for zirconium-containing samples. This may be due to distortions resulting from the overlap of a $1089 \mathrm{~cm}^{-1}$ band, which is intrinsic to $\mathrm{ZrO}_{2}$. In addition, the transition to a high-frequency region may be due to an increase of zeolite $\mathrm{Si} / \mathrm{Al}$ ratio. This can happen only through aluminium removing. The latter may indicate that zirconium, being a four-coordinated isomorphic substitute of the aluminium atoms during steaming of samples, increases the zeolite $\mathrm{Si} / \mathrm{Al}$ ratio and, accordingly, its thermal stability. The possibility of the existence of gallium, germanium, tin and 

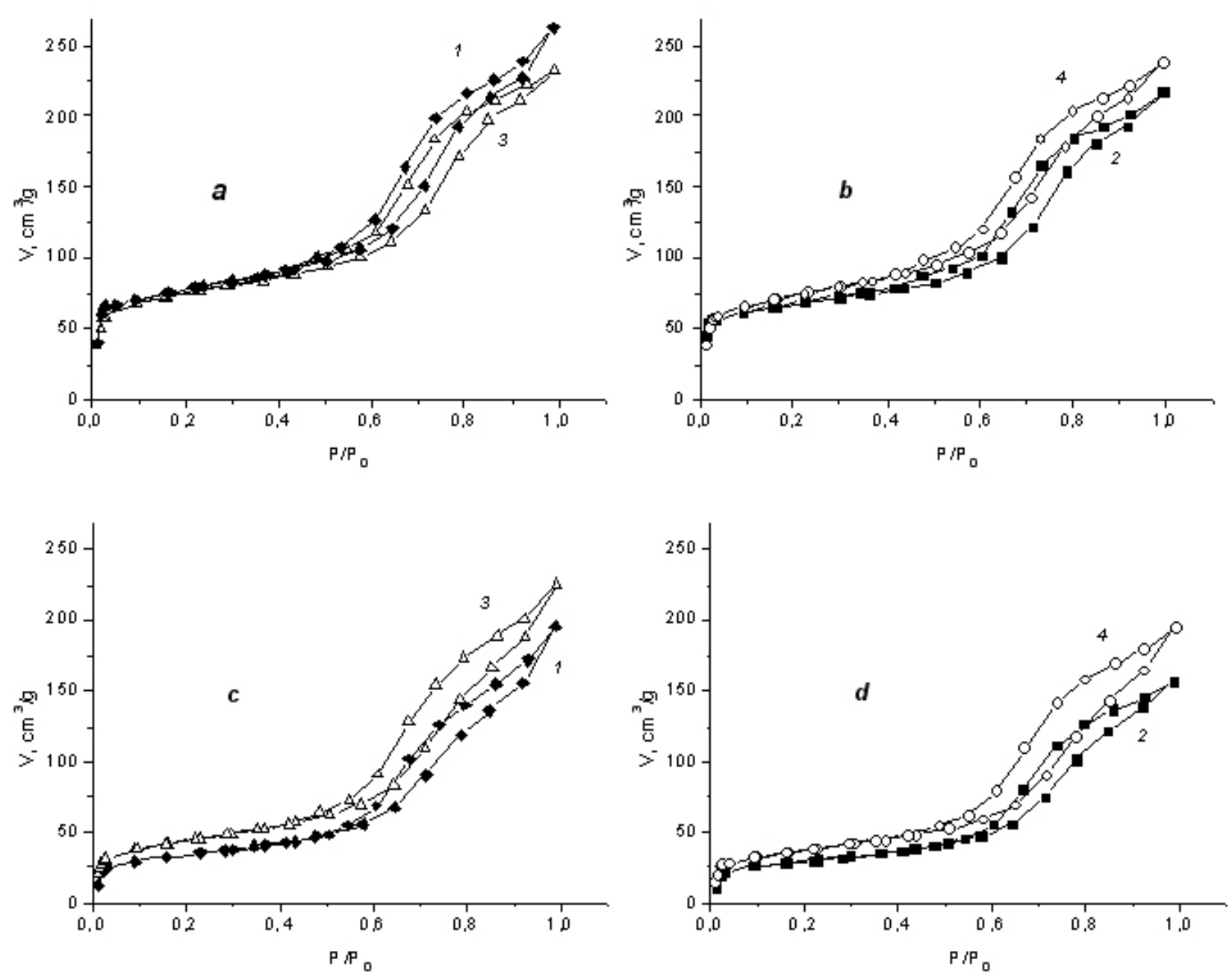

Fig. 2. Low temperature nitrogen adsorption/desorption isotherms for the fresh $(\mathrm{a}, \mathrm{b})$ and steamed $(\mathrm{c}, \mathrm{d})$ samples: 1 - H-FCC, 2 - HLa-FCC, 3 - H4Zr-FCC, and 4 - H6Zr-FCC

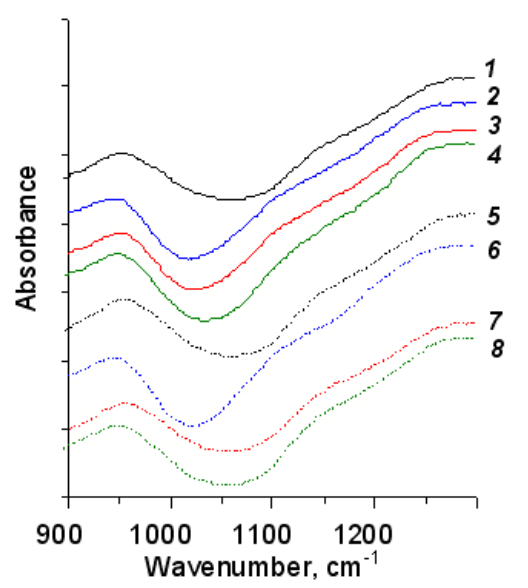

Fig. 3. FTIR spectra of the synthesized fresh $(1-\mathrm{H}-\mathrm{FCC}$, 2 - HLa-FCC, 3 - H4Zr-FCC, and $4-\mathrm{H} 6 \mathrm{Zr}-\mathrm{FCC})$ and steamed (5 - H-FCC-TWT, 6 - HLa-FCC-TWT,

7 - H4Zr-FCC-TWT, and $8-$ H6Zr-FCC-TWT) FCC samples zirconium-containing zeolites was shown previously $[14,15]$. In the case of lanthanum, its entry into the zeolite lattice obviously does not occur.

Fresh and steamed catalysts were investigated in a test reaction of cumene cracking. Fresh samples in the pulse cumene cracking showed a high activity in the whole diapason (Fig. 4,a). Cumene conversion was $70-100 \%$, the highest was observed for the fresh $\mathrm{H}-\mathrm{FCC}$ sample and the lowest was detected for the HLa-FCC one. Samples modified by zirconium showed lower activity than H-FCC. After TWT treatment, a considerable decrease in activity occurred (Fig. 4,b). However, Zr-containing samples retained their activity better than pure hydrogencontaining form H-FCC-TWT and La-containing HLa-FCC-TWT samples. The conversion of cumene for the $\mathrm{HZr}$-FCC-TWT sample was by $20-30 \%$ higher than that for the H-FCC-TWT sample. It seems that zirconium, in addition to the stabilizing 

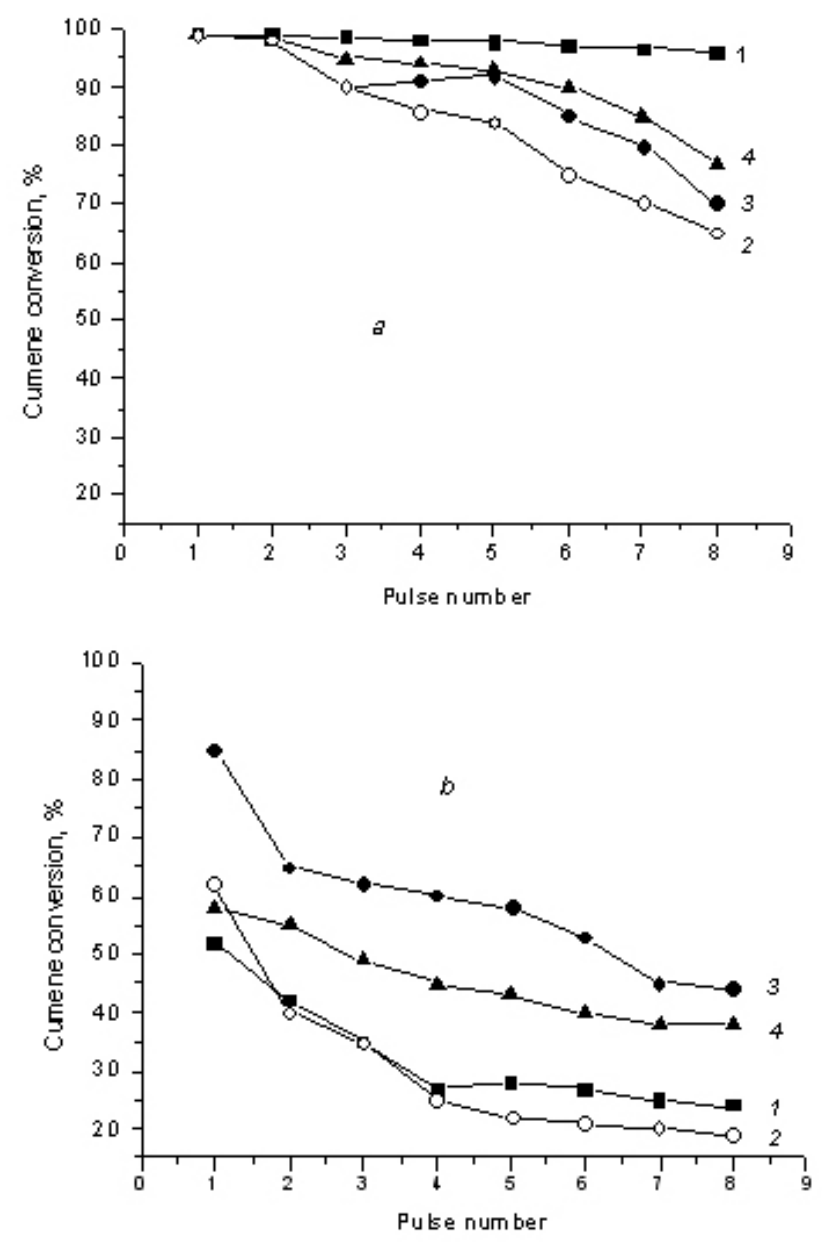

Fig. 4. Cumene conversion (X) over fresh samples (a) and steamed ones (b) as a function of pulse number: $1-\mathrm{H}-\mathrm{FCC}$,

2 - HLa-FCC, 3 - H4Zr-FCC, 4 - H6Zr-FCC

effect of the kaolin matrix [6,7], enhances the thermostability of the zeolite phase.

\section{Conclusions}

The addition of lanthanum and zirconium to the FCC catalyst was evaluated from the point of view of porous characteristics of the synthesized samples and their activity and stability.

XRD results and low temperature nitrogen adsorption/desorption data confirmed a smaller destruction of zeolite phase during TWT treatment for $\mathrm{Zr}$-containing samples than for La-containing ones. Modification of both elements led to a decrease in BET and micropores surface, but zirconium promoted the stability of zeolite phase after thermalwater treatment and, as a consequence, an average radius of the samples become smaller.

Zirconium stabilizing effect was treated by its isomorphous exchange of aluminium lattice with an increase in $\mathrm{Si} / \mathrm{Al}$ ratio.

FCC catalyst with $6.5 \%$ of $\mathrm{Zr}$ demonstrated the highest activity among stabilized samples. The conversion of cumene was $50-85 \%$ for this catalyst, whereas it was only $25-50 \%$ for the unmodified sample.

\section{Acknowledgments}

The authors would like to express their gratitude to Eng. D.V. Molodyi for conducting low temperature nitrogen adsorption/desorption analysis of the samples.

\section{REFERENCES}

1. Sadaghbeigi $R$. Fluid catalytic cracking handbook: an expert guide to the practical operation, design, and optimization of FCC units. 2nd Ed. - Amsterdam: Elsevier, 2012. - 352 p.

2. Crude oil to chemicals: light olefins from crude oil / Corma A., Corresa E., Mathieu Y., Sauvanaud L., Al-Bogami S., Al-Ghramib M.S., Bourane A. // Catal. Sci. Technol. - 2017. Vol.7. - P.12-46.

3. Nishimura $Y$. Development of catalytic cracking process and catalysts // Adv. Porous Mater. - 2017. - Vol.5. - P.17-25.

4. Xи Y., Cui S. A novel fluid catalytic cracking process for maximizing iso-paraffins: from fundamentals to commercialization // Front. Chem. Sci. Eng. - 2018. - Vol.12. - No. 1. - P.9-23.

5. Occelli M.L., O'Connor P. Fluid catalytic cracking V. Amsterdam: Elsevier, 2001. - 356 p.

6. Do pytann 'ya pro stabil'nist' H-form tseolitiv / Patrylak L.K., Likhnevsky R.V., Kukushkina A.V., et al. // Ukrainskii Khimicheskii Zhurnal. - 2000. - Vol.66. - P.100-103.

7. Adsorption properties of zeolite-containing microspheres and FCC catalysts based on Ukrainian kaolin / Patrylak L., Likhnyovskyi R., Vypyraylenko V., Leboda R., SkubiszewskaZieba J., Patrylak K. // Adsorpt. Sci. Technol. - 2001. - Vol.19. - P.525-540.

8. Sintez i izuchenie katalizatora krekinga na osnove kaolina Prosyanovskogo mestorozhdeniya / K.I. Patrylak, V.I. Nazarok, L.K. Patrylak, et al. // Russ. J. Appl. Chem. - 1999. - Vol.72. P.798-803,

9. Patrylak $L$. Chemisorption of the Lewis bases on zeolites - a new interpretation of the results / Adsorpt. Sci. Technol. 1999. - Vol.17. - No. 2. - P.115-123.

10. Breck D.W. Zeolite molecular sieves: structure, chemistry, and use. - New York: Whiley, 1973.

11. Patrylak $L$. Chemisorption and the distribution of acid Y zeolite cumene cracking products // Adsorpt. Sci. Technol. 2000. - Vol.18. - No. 5. - P.399-408.

12. Adsorption by powders and porous solids. Principles, methodology and applications / Rouquerol F., Rouquerol J., Llewellyn P., et al. - San Diego: Academic Press. - 2012.

13. Changing the characteristics and properties of zeolite $\mathrm{Y}$ and nano-anatase in the formation of a nano-anatase/Y composite with improved photocatalytic and adsorption properties / Domoroshchina E.N., Chernyshev V.V., Kuz'micheva G.M., 
Dorokhov A.V., Pirutko L.V., Kravchenko G.V., Chumakov R.B. // Appl. Nanosci. - 2018. - Vol.8. - No. 1-2. - P.19-31.

14. Effect of production conditions of hierarchical SnAl-BEA zeolites on their acidity and catalytic activity in tandem process for the production of 4-methoxybenzyl-sec-butyl ether / Kurmach M.M., Popovych N.O., Kyriienko P.I., Yaremov P.S., Khyzhun O.Y., Andreev O.V., Shvets O.V. // Theor. Exp. Chem. - 2019. - Vol.55. - No. 1. - P.56-63.

15. Effect of introduction of $\mathrm{B}^{3+}$ or $\mathrm{Al}^{3+}$ ions in the structure of $\mathrm{Ti}-, \mathrm{Sn}-$, and $\mathrm{Zr}$-containing hierarchical zeolites on the concentration of Lewis and Brønsted acid centers / Kurmach M.M., Yaremov P.S., Skoryk M.O., Shvets O.V. // Theor. Exp. Chem. - 2016. - Vol.52. - No. 3. - P.190-196.

Received 24.06.2019

\section{ВПЛИВ МОДИФІКАЦІЇ Zr ТА La НА ПОРИСТІ ХАРАКТЕРИСТИКИ ТА КАТАЛІТИЧНУ АКТИВНІСТЬ СИНТЕЗОВАНИХ IN SITU МІКРОСФЕРИЧНИХ КАТАЛІЗАТОРІВ КРЕКІНГУ}

\section{Л.К. Патриляк, О.П. Пертко, В.А. Поважний, О.В. Мельничук}

Сучасні мікросферичні каталізатори крекінгу для багатотоннажних процесів нафтопереробки працюють при надзвичайно важких умовах, а тому повинні мати належну стабільність до дії високих температур та водяної пари. Метою даної роботи було порівняння впливу модифікування Лантаном та Цирконієм на пористі характеристики та каталітичну активність свіжого та парообробленого мікросферичних каталізаторів крекінгу, синтезованих на основі українського каоліну. Синтезований вихідний зразок містив $30 \%$ щеоліту типу $Y$, який було переведено у Н-форму перед введенням Лантану та Цирконію. Модифікація призвела до деякого падіння поверхні за БЕТ та мікропористості зразків, що суттєво інтенсифікувалося після парооброблення. У випадку Цирконію таке падіння було меншим. Вплив модифікування каталізаторів на коливання структурних елементів иеолітної решітки досліджували методом ГЧ-спектроскопї̈ з Фур'є перетворенням. Спостережений зсув частоти поглинання смуги при $1070 \mathrm{~cm}^{-1}$, що відповідає асиметричним коливанням тетраедрів після відповідних модифікацій, свідчить про ізоморфне заміщення атомів Алюмінію чотирикоординованим Цирконієм. Парооброблений зразок з 6,5\% вмістом Цирконію демонструе найвищу конверсію кумолу, за якою він переважає немодифікований зразок на 20-30\%. Таким чином, модифікація синтезованих каталізаторів крекінгу Цирконієм позитивно впливає як на адсорбційні, так $і$ на каталітичні властивості парооброблених зразків.

Ключові слова: мікросферичний каталізатор крекінгу, Цирконій, Лантан, пористі характеристики, каталітична активність.

\section{INFLUENCE OF MODIFICATION BY Zr AND La ON THE POROUS CHARACTERISTICS AND CATALYTIC ACTIVITY OF IN SITU SYNTHESIZED MICROSPHERICAL CRACKING CATALYSTS}

\author{
L.K. Patrylak *, O.P. Pertko, V.A. Povazshnyi, O.V. \\ Melnychuk V.P.
}

Kukhar Institute of Bioorganic Chemistry and Petrochemistry of the National Academy of Sciences of Ukraine, Kyiv, Ukraine

\section{*e-mail: lkpg@ukr.net}

Up-to-date fluid catalytic cracking catalysts for large-tonnage refining processes work under extremely hard conditions and need to have a high stability to the thermal and steam treatment. Therefore, the purpose of this work was to compare the effect of lanthanum and zirconium additives on the porous characteristics and catalytic activity of the microspherical cracking catalysts in fresh and steamed form that were synthesized based on the Ukrainian kaolin. The synthesized initial sample contained $30 \% Y$ zeolite that was transferred to the $H$-form before the modification by lanthanum and zirconium. The modification led to some decrease in BET surface and samples microporosity, which was substantially intensified after steaming. In the case of zirconium, such a decrease was less than for lanthanum. The effect of the catalysts modification on the vibrations of the structural components of the zeolite lattice was investigated by FTIR spectroscopy. The observed shifts of absorbance frequencies of the bond at $1070 \mathrm{~cm}^{-1}$, which correspond to the asymmetric vibrations of tetrahedra after corresponding modifications, indicated the isomorphic substitution of the aluminum atoms by zirconium ones. The steamed samples with the zirconium content of $6.5 \%$ demonstrated the highest conversion of cumene cracking (an increase by 20-30\% as compared with the unmodified sample). Therefore, the modification of fluid catalytic cracking catalysts by zirconium affects both on the adsorption and on the catalytic properties of the steamed samples.

Keywords: fluid catalytic cracking catalyst; zirconium; lanthanum; porous characteristics; catalytic activity.

\section{REFERENCES}

1. Sadaghbeigi R., Fluid catalytic cracking handbook: an expert guide to the practical operation, design, and optimization of FCC units. Elsevier, Amsterdam, 2012. 352 p.

2. Corma A., Corresa E., Mathieu Y., Sauvanaud L., Al-Bogami S., Al-Ghrami M.S., Bourane A. Crude oil to chemicals: light olefins from crude oil. Catalysis Science \& Technology, 2017, vol. 7, pp. 12-46.

3. Nishimura Y. Development of catalytic cracking process and catalysts. Advanced Porous Materials, 2017, vol. 5, pp. 17-25.

4. Xu Y., Cui S. A novel fluid catalytic cracking process for maximizing iso-paraffins: from fundamentals to commercialization. Frontiers of Chemical Science and Engineering, 2018, vol. 12, pp. 9-23.

5. Occelli M.L., O'Connor P., Fluid catalytic cracking $V$. Elsevier, Amsterdam, 2001. 356 p.

6. Patrylak L.K., Likhnevsky R.V., Kukushkina A.V. Do pytann'ya pro stabil'nist' $\mathrm{H}$-form tseolitiv [About stability of zeolite in H-form]. Ukrainskii Khimicheskii Zhurnal, 2000, vol. 66, pp. 100-103. (in Ukrainian).

7. Patrylak L., Likhnyovskyi R., Vypyraylenko V., Leboda R., Skubiszewska-Zieba J., Patrylak K. Adsorption properties of zeolite-containing microspheres and FCC catalysts based on Ukrainian kaolin. Adsorption Science \& Technology, 2001, vol. 19 , pp. 525-540 
8. Patrylak K.I., Nazarok V.I., Patrylak L.K. Sintez i izuchenie katalizatora krekinga na osnove kaolina Prosyanovskogo mestorozhdeniya [Synthesis and investigation of cracking catalyst based on Prosyana kaolin]. Zhurnal Prikladnoi Khimii, 1999, vol. 72, pp. 798-803. (in Russian).

9. Patrylak L.K. Chemisorption of the Lewis bases on zeolites - a new interpretation of the results. Adsorption Science \& Technology, 1999, vol. 17, no. 2, pp. 115-123.

10. Breck D.W., Zeolite molecular sieves: structure, chemistry, and use. Whiley, New York, 1973. $771 \mathrm{p}$.

11. Patrylak L. Chemisorption and the distribution of acid Y zeolite cumene cracking products. Adsorption Science \& Technology, 2000, vol. 18, no. 5, pp. 399-408.

12. Rouquerol F., Rouquerol J., Llewellyn P., Adsorption by powders and porous solids. Principles, methodology and applications. Academic Press, San Diego, 2012. 646 p.

13. Domoroshchina E.N., Chernyshev V.V., Kuz'micheva G.M., Dorokhov A.V., Pirutko L.V., Kravchenko G.V., Chumakov R.B. Changing the characteristics and properties of zeolite $\mathrm{Y}$ and nanoanatase in the formation of a nano-anatase/Y composite with improved photocatalytic and adsorption properties. Applied Nanoscience, 2018, vol. 8, pp. 19-31.

14. Kurmach M.M., Popovych N.O., Kyriienko P.I., Yaremov P.S., Khyzhun O.Y., Andreev O.V., Shvets O.V. Effect of production conditions of hierarchical SnAl-BEA zeolites on their acidity and catalytic activity in tandem process for the production of 4-methoxybenzyl-sec-butyl ether. Theoretical and Experimental Chemistry, 2019, vol. 55, pp. 56-63.

15. Kurmach M.M., Yaremov P.S., Skoryk M.O., Shvets O.V. Effect of introduction of $\mathrm{B}^{3+}$ or $\mathrm{Al}^{3+}$ ions in the structure of $\mathrm{Ti}-, \mathrm{Sn}-$, and $\mathrm{Zr}$-containing heirarchical zeolites on the concentration of Lewis and Brønsted acid centers. Theoretical and Experimental Chemistry, 2016, vol. 52, pp. 190-196. 